\section{Magnesium isotopic systematics of metapelite in the deep crust and implications for granite petrogenesis}

\section{S.-J. Wang ${ }^{1 *}$, F.-Z. Teng ${ }^{1 *}$, F. Bea ${ }^{2}$}

\section{Abstract} Fluid-absent reactions that involve the breakdown of hydrous minerals produce granites control on the chemical compositions of granites, but how and to what extent it may influence their isotopic signtures is poorly understood. their isotopic signatures is poorly understod. Here we present Mg isotope data for a suite of amphibolite-to granulite-facies metapelites as well as the biotite and garnet minerals therein from the Ivrea Zone, NW Italy. The mineralogy of metapelites changes from biotitedominated in the amphibolite-facies to garnet-dominated in the granulite-facies. The bulk $\mathrm{Mg}$ isotopic compositions ( $\mathrm{O} \mathrm{Mg}=-0.23$ to $+0.20 \%$ ) do not correlate with metamorphic grade, indicating negligible $\mathrm{Mg}$ isotopic variation caused by metamorphism of metapelites. By contrast, the $\delta^{26} \mathrm{Mg}$ values of biotite vary widely from -0.08 to $+1.10 \%$, and increase with metamorphic grade. Correspondingly, coexisting garnets become isotopically heavy $(-1.22$ to $+0.10 \%$ ) as metamorphism proceeds, in order to equilibrate with the biotite, with a fractionation equation of $10^{3} \ln \alpha_{\text {biotite-garnet }}=0.96 \times 10^{6} / \mathrm{T}^{2}$, which can be used as a novel geothermometer. Our results indicate a nearly closed system for $\mathrm{Mg}$ isotopes of metapelites during metamorphism, and the bulk $\mathrm{Mg}$ isotopic compositions are therefore reconciled by the shifting garnet and biotite modes accompanied by increasing mineral $\delta^{26} \mathrm{Mg}$ values. The systematic $\mathrm{Mg}$ isotopic variation in the biotite and garnet implies a possible $\mathrm{Mg}$ isotope fractionation between melts and residues during biotite dehydration melting, which makes $\mathrm{Mg}$ isotopes a potential monitor of crustal melting and a tracer of granite petrogenesis.

\section{Received 17 April 2015 | Accepted 5 June 2015 | Published 22 June 2015}

Isotope Laboratory, Department of Earth and Space Sciences, University of Washington, Seattle, WA 98195-1310, USA

. Spain

\title{
Introduction
}

Fluid-absent incongruent melting of hydrous minerals such as muscovite, biotite and amphibole that takes place in the continental crust give rise to large volumes of granitoids (Clemens and Vielzeuf, 1987; Clemens and Watkins, 2001). Pelitic rocks containing abundant mica minerals are the most fertile lithologies in the deep (middle and lower) continental crust, and can produce as much as 50 vol.\% melt as the temperature rises above $700{ }^{\circ} \mathrm{C}$ (Le Breton and Thompson, 1988; Vielzeuf and Holloway, 1988). Dry, granulitic residues after an early melt extraction are relatively refractory but may still be melted at higher temperatures (e.g., $>830^{\circ} \mathrm{C}$; Whalen et al., 1987). Consequently, the elemental and isotopic diversity of granitoids results from a combination of protolith heterogeneities, melting reaction patterns, melt extraction and ascending processes (Barbero et al., 1995; Bea, 1996; Patiño Douce, 1999; Brown, 2007; Stevens et al., 2007; Clemens and Stevens, 2012; Lee and Morton, 2015).

Magnesium $(\mathrm{Mg})$ in anatectic melts may come exclusively from the mafic hydrous minerals participating in the melting reactions. Taking anatexis of the metapelitic system as an example, micas (mainly muscovite and biotite) in the source play the first order control on the $\mathrm{Mg}$ isotopic composition $\left(\delta^{26} \mathrm{Mg}\right)$ of resulting melts. The $\delta^{26} \mathrm{Mg}$ values of global granites range from -0.45 to +0.44 \%o (Shen et al., 2009; Li et al., 2010; Liu et al., 2010; Telus et al., 2012; Ling et al., 2013; Wang et al., 2014b), far exceeding that of normal mantle rocks $(-0.25 \pm 0.07$ $\%$; Teng et al., 2010a). While protolith heterogeneity (i.e. sedimentary vs. igneous protoliths) partially explains this Mg isotopic variation (Shen et al., 2009), metamorphic overprints on potential granitoid sources, with concomitant changes of source mineralogy, may play an important, but poorly understood, role as well.

Here, we present $\mathrm{Mg}$ isotope data for 12 well-characterised metapelites and 13 mineral separates (biotite and garnet) therein from the Ivrea Zone, NW Italy (Bea and Montero, 1999; Qiu et al., 2011). These metapelites represent a typical prograde metamorphic sequence from middle amphibolite- to granulite-facies, and thus are ideal samples for studying the behaviour of $\mathrm{Mg}$ isotopes under the middle-lower crustal conditions. Our results indicate that the bulk metapelites display a considerable $\mathrm{Mg}$ isotopic variation $\left(\delta^{26} \mathrm{Mg}=-0.23\right.$ to $+0.20 \%$ o) that does not correlate with metamorphic grade. By contrast, the $\delta^{26} \mathrm{Mg}$ values of biotite $(-0.08$ to $+1.10 \%$ o) and garnet $(-1.22$ to +0.10 $\%$ ) vary more significantly and increase as metamorphism proceeds, which makes $\mathrm{Mg}$ isotopes a potential tracer for crustal melting and granite petrogenesis.

\section{Ivrea Zone Metapelites}

The Ivrea Zone, NW Italy, represents an exposed section of the middle to lower crust and preserves a transition from amphibolite- to granulite-facies metapelites (e.g., Zingg, 1984). The metamorphic condition for these metapelites ranges from ca. 4 kbar at $500{ }^{\circ} \mathrm{C}$ to ca.10 $12 \mathrm{kbar}$ at $>900{ }^{\circ} \mathrm{C}$ (Henk et al., 1997; Bea and 
Montero, 1999; Luvizotto and Zack, 2009; Redler et al., 2011). The modal abundance of garnet in metapelites increases at the expense of biotite with increasing metamorphic grade following the metamorphic reaction: biotite + sillimanite + plagioclase + quartz $\rightarrow$ garnet $+\mathrm{K}$-feldspar + rutile + melt. This reaction proceeds until the biotite is almost entirely consumed in granulite-facies metapelites (Bertolani and Garuti, 1970; Schmid and Wood, 1976). The metapelites in the Ivrea Zone are divided into three zones from low to high metamorphic grade based on the biotite/garnet ratio (Bea and Montero, 1999): the kinzigite zone that corresponds to metapelites with modal biotite/garnet $>2$, the transition zone in which the modal biotite/garnet is between 0.5 and 2, and the stronalite zone where modal biotite/ garnet is $<0.5$ (Fig. S-1). Twelve representative samples of metapelites and garnetbiotite mineral pairs from the three zones were studied for Mg isotopes (Fig. S-1).

\section{Results}

The Mg isotopic data, along with details of the analytical methods, are presented in the Supplementary Information and summarised in Figure 1. The bulk metapelites display a considerable variation in $\mathrm{Mg}$ isotopic composition, with $\delta^{26} \mathrm{Mg}$ ranging from -0.23 to $+0.20 \%$ o for the kinzigite zone, from -0.10 to $+0.14 \%$ o for the transition zone, and from -0.10 to $+0.12 \%$ for the stronalite zone. No correlation between bulk $\delta^{26} \mathrm{Mg}$ and metamorphic grade is observed (Fig. 1). By contrast, $\delta^{26} \mathrm{Mg}$ values of the associated mineral separates display wider ranges and increase systematically with metamorphic grade (Fig. 1). The Mg isotopic compositions of garnet become progressively heavy from the kinzigite zone $\left(\delta^{26} \mathrm{Mg}=-1.10\right.$ to $\left.-1.22 \%\right)$ to the transition zone $\left(\delta^{26} \mathrm{Mg}=-0.34 \%\right)$ and finally to the stronalite zone $\left(\delta^{26} \mathrm{Mg}=-0.03\right.$ to $+0.10 \%$; Fig. 1$)$. The biotite is isotopically heavier than coexisting garnet, with $\delta^{26} \mathrm{Mg}$ increasing from the kinzigite zone $(-0.08$ to $+0.30 \%$ o) through the transition zone $(+0.58 \%$ o $)$ to the stronalite zone (+1.00 to $+1.10 \%$; Fig. 1$)$

\section{Discussion and Conclusion}

Minerals with low $\mathrm{Mg}$ coordination numbers $(\mathrm{CN})$ and thus strong $\mathrm{Mg}-\mathrm{O}$ bonds preferentially incorporate heavy $\mathrm{Mg}$ isotopes. Given the difference in $\mathrm{Mg}$ coordination geometry between biotite $(\mathrm{CN}=6)$ and garnet $(\mathrm{CN}=8)$, substantial inter-mineral isotope fractionation is expected, but the exact fractionation factor has not been determined. Our study shows that the Mg isotope fractionation between biotite and garnet is significant, in the range of $0.92 \sim 1.48 \%$ o (Fig. 2). Different mineral fragments from the same metapelite yield identical $\mathrm{Mg}$ isotopic compositions (Table S-1), suggesting negligible intra-mineral Mg isotopic variations and thus implying the equilibrium $\mathrm{Mg}$ isotope fractionation The degree of equilibrium isotope fractionation is a function of temperature,

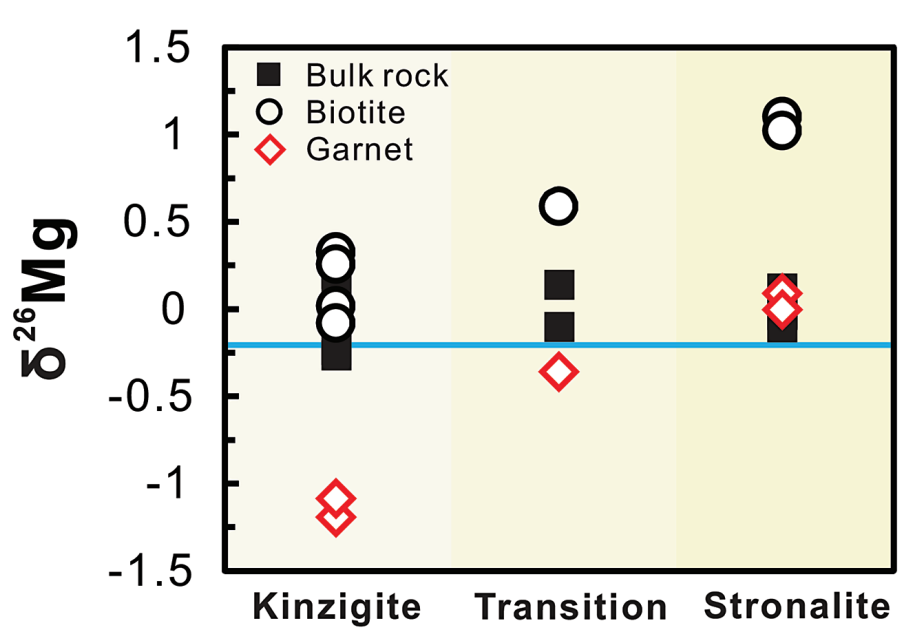

Figure 1 Magnesium isotopic compositions versus metamorphic grade for the bulk metapelites, biotites and garnets. The average value of bulk upper continental crust $\left(\delta^{26} \mathrm{Mg}=-0.22 \%\right)$ is represented by the blue line (Li et al., 2010). Data are reported in Table S-1.

with $10^{3} \ln \alpha_{\text {biotite-garnet }}=0.96 \times 10^{6} / \mathrm{T}^{2}\left(\mathrm{R}^{2}=0.7\right.$; Fig. 2$)$. This fractionation equation is very similar to those previously reported for garnet-clinopyroxene pairs from eclogites (Fig. 2) (Li et al., 2011; Wang et al., 2012, 2014a,b; Huang et al., 2013), which is reasonable since the $\mathrm{Mg}$ coordination geometry in biotite is the same as in clinopyroxene. The relatively high scatter of data may reflect an additional but small effect from pressure, as first-principles calculations suggest that the equilibrium inter-mineral $\mathrm{Mg}$ isotope fractionation is also pressure-dependent i.e. the degree of fractionation is suppressed as pressure decreases (Huang et al, 2013). Nevertheless, our results indicate for the first time that Mg isotopes might be used as a novel geothermometer for garnet and biotite-bearing rocks.

The $\delta^{26} \mathrm{Mg}$ values of the bulk-rock do not correlate with metamorphic grade (Fig. 1), suggesting that metamorphic dehydration/partial melting during the transition from amphibolite- to granulite-facies caused negligible change of $\mathrm{Mg}$ isotopes of metapelites. This conclusion is consistent with previous studies that show limited $\mathrm{Mg}$ isotope fractionation by either low- or high-temperature metamorphic dehydration (Teng et al., 2013; Li et al., 2014; Wang et al., 2014b). During metamorphism, the majority of $\mathrm{Mg}$ in rocks is inherited by newly formed minerals without significant loss, hence $\mathrm{Mg}$ isotope variations in the bulk metamorphic rocks are not directly related to metamorphic grade. Therefore, the heavy $\mathrm{Mg}$ isotopic compositions of the studied metapelites indicate that their protoliths were the residues of chemical weathering, from which light Mg isotopes had been progressively leached to the hydrosphere (e.g., Tipper et al., 2006; Teng et al., 2010b). 


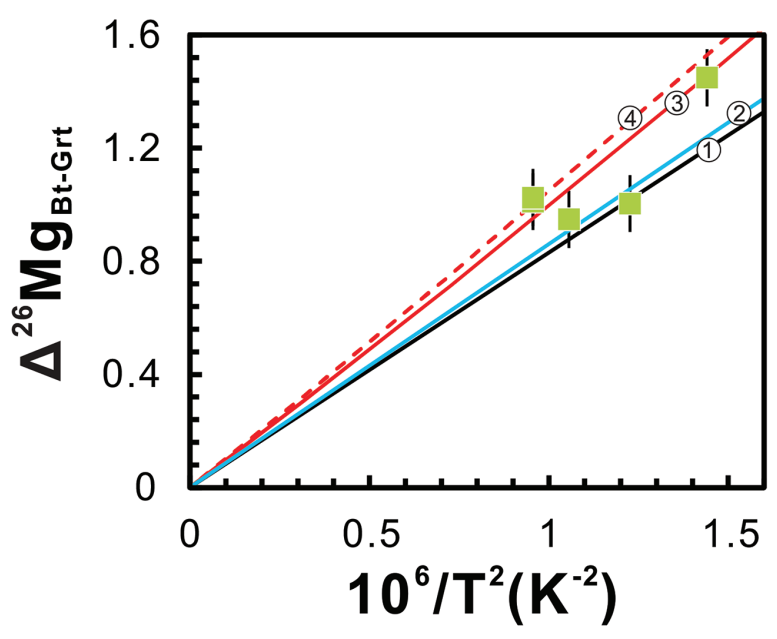

Figure 2 Magnesium isotope fractionation between biotite and garnet $\left(\Delta^{26} \mathrm{Mg}_{\mathrm{Bt}-\mathrm{Grt}}=\delta^{26} \mathrm{Mg}_{\mathrm{B}}\right.$ $-\delta^{26} \mathrm{Mg}_{\mathrm{Grt}}$ ) as a function of $1 / \mathrm{T}^{2}$. Empirically and theoretically determined equilibrium equations of clinopyroxene-garnet $\mathrm{Mg}$ isotope fractionation are also shown for comparison. (1) is an empirical equilibrium fractionation equation of $\Delta^{26} \mathrm{Mg}$ clinopyroxene-garnet $=0.83 \times 10^{6} / \mathrm{T}^{2}$ from Li et al. (2011); (2) is also an empirical equilibrium fractionation equation of $\Delta^{26} \mathrm{Mg}_{\text {clin }}$

$=0.86 \times 10^{6} / \mathrm{T}^{2}$ from Wang et al. (2012); (3) and (4) represent the theoretically determined equilibrium fractionation equations at pressures of 0 and $10 \mathrm{kbar}$ (Huang et al., 2013), respectively. The temperatures for the studied metapelites, estimated using biotite-garnet $\mathrm{Mg}$-Fe exchange geothermometer, are from Bea and Montero (1999). Data are reported in Table S-1.

The Mg budget in metapelites is exclusively controlled by biotite and garnet, which is opposite to other isotopic systems (such as $\mathrm{Sr}, \mathrm{Nd}, \mathrm{Li}$, and $\mathrm{O}$ ) that are hosted in other minerals in addition to biotite and garnet. Due to the prograde reaction of biotite + sillimanite + plagioclase + quartz $\rightarrow$ garnet + K-feldspar + rutile + melt (Schnetger, 1994; Luvizotto and Zack, 2009), the mineralogy of metapelites changes from biotite-dominated at amphibolite-facies to garnetdominated at granulite-facies (Fig. S-2). At the same time, both biotite and garnet $\delta^{26} \mathrm{Mg}$ values become more positive (Fig. S-2). The coherent garnet - biotite $\mathrm{Mg}$ isotopic variations mainly result from the fact that the partitioning of $\mathrm{Mg}$ and its isotopes between garnet and biotite proceeds in accordance with their moda abundance within a nearly closed system. For example, biotites dominate the $\mathrm{Mg}$ budget in amphibolite-facies pelites, and consequently biotite $\delta^{26} \mathrm{Mg}$ values are, as expected from mass balance, similar to the bulk-rock values, whereas garnet $\delta^{26} \mathrm{Mg}$ values are significantly lighter because of the coordination geometry controlled inter-mineral fractionation (Fig. 1). During prograde metamorphism, isotopically heavy $\mathrm{Mg}$ released from the breakdown of biotite is progressively incorporated into the garnet, driving garnets towards high $\delta^{26} \mathrm{Mg}$, close to the bulk-rock values (Fig. 1), and simultaneously shifting residual biotites to more ${ }^{26} \mathrm{Mg}$ enriched.
The systematic variation of mineral $\mathrm{Mg}$ isotopic compositions during middle-lower crustal metamorphism indicates the possibility of $\mathrm{Mg}$ isotope fractionation during crustal melting. As temperature rises, metapelites in the deep continental crust undergo two stages of dehydration melting: first as muscovite, and second as biotite (e.g., Le Breton and Thompson, 1988; Clemens, 2003). Muscovite dehydration melting (e.g., muscovite + plagioclase + quartz $\rightarrow$ melt + K-feldspar + sillimanite + biotite) would not produce significant Mg isotope fractionation between melts and residues because minerals participating in the melting reactions have the same $\mathrm{Mg}$ coordination geometry and hence would display limited inter-mineral $\mathrm{Mg}$ isotope fractionations. By contrast, dehydration melting of biotite at higher temperatures as discussed above (e.g., biotite + sillimanite + plagioclase + quartz $\rightarrow$ garnet $+\mathrm{K}$-feldspar + rutile + melt $)$ is able to generate highly variable $\delta^{26} \mathrm{Mg}$ for the melt. Melting reaction consistent with the biotite dehydration melting experiment of Patiño Douce and Johnston (1991) is modelled to investigate the behaviour of $\mathrm{Mg}$ isotopes during crustal melting (Fig. S-3). With progressive melting, $\mathrm{Mg}$ isotopic compositions of residual biotite become heavier accompanied by the growth of peritectic garnet. Correspondingly, the resulting melts become isotopically heavier (Fig. S-3). Therefore, multiple pulses of granitic magmas generated from the same protolith could have $\delta^{26} \mathrm{Mg}$ values that vary by up to $\sim 1 \%$ (Fig. S-3).

Our results also have important implications on tracing intra-crustal differentiation by using $\mathrm{Mg}$ isotopes. The granulite-facies lower crustal rocks that have undergone a previous melt extraction would contain only small amounts of hydrous minerals (e.g., biotite and amphibole) coexisting with a garnet-dominated solid peritectic mineral assemblage (Fig. 3). As expected from the closed-system $\mathrm{Mg}$ isotopic evolution during metamorphism, these

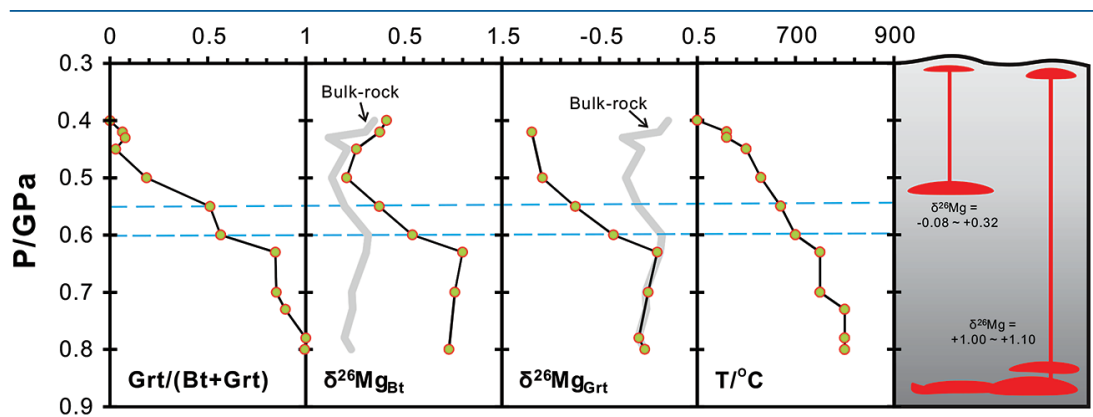

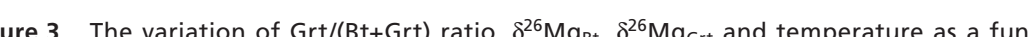
tion of pressure variation of $\mathrm{Grt} /(\mathrm{Bt}+\mathrm{Grt})$ ratio, $\delta^{26} \mathrm{Mg}_{\mathrm{Bt}}, \delta^{26} \mathrm{Mg}_{\mathrm{Grt}}$ and temperature as a funcmelts at different crustal depths. For those samples whose mineral separates are unavailable, $\mathrm{Mg}$ isotopic compositions of biotite and garnet are calculated based on the mineral modes and chemistries, assuming an inter-mineral $\mathrm{Mg}$ isotope fractionation of $~ 1.00 \%$. The mineral modes, compositions and temperatures are from Bea and Montero (1999). 
biotites and amphiboles would have heavier $\mathrm{Mg}$ isotopic compositions than those in the amphibolite-facies middle crust. Hence, dehydration melting of a granulite-facies source in the lower crust at high temperatures $\left(>850^{\circ} \mathrm{C}\right)$ would generate melts that have higher $\delta^{26} \mathrm{Mg}$ values than those derived from dehydration melting of an amphibolite-facies source in the middle crust. Further studies of $\mathrm{Mg}$ isotopes in granites may help to fingerprint their source and melting mechanism in the deep continental crust.

\section{Acknowledgements}

We would like to thank Roberta Rudnick for sharing samples, Aaron Brewer and Kwan-Nang Pang for thoughtful discussion, Ethan Baxter, Cin-Ty Lee and Bruce Watson for insightful comments. This work was financially supported by the national Science Foundation EAR-0838227, EAR-1056713, and EAR-1340160

Editor: Bruce Watson

\section{Additional Information}

Supplementary Information accompanies this letter at www.geochemicalperspectivesletters.org/article1508

Reprints and permission information is available online at http://www geochemicalperspectivesletters.org/copyright-and-permissions

Cite this letter as: Wang, S.-J., Teng, F.-Z., Bea, F. (2015) Magnesium isotopic systematics of metapelite in the deep crust and implications for granite petrogenesis. Geochem. Persp. Let. 1, 75-83.

\section{References}

Barbero, L., Villaseca, C., Rogers, G., Brown, P. (1995) Geochemical and isotopic disequilibrium in crustal melting: an insight from the anatectic granitoids from Toledo, Spain. Journal of Geophysical Research: Solid Earth 100, 15745-15765.

BEA, F. (1996) Controls on the trace element composition of crustal melts. Geological Society of America Special Papers 315, 33-41.

BEA, F., MONTERO, P. (1999) Behavior of accessory phases and redistribution of Zr, REE, Y, Th, and $\mathrm{U}$ during metamorphism and partial melting of metapelites in the lower crust: an example from the Kinzigite Formation of Ivrea-Verbano, NW Italy. Geochimica et Cosmochimica Act 63, 1133-1153.

BERTOLANI, M., GARUTI, G. (1970) Aspetti petrografici della formazione basica Ivrea-Verbano in Val Sessera (Vercelli). Rendiconti Societa Italiana di Mineralogia e Petrografia 32, 434-474.

BRown, M. (2007) Crustal melting and melt extraction, ascent and emplacement in orogens: mechanisms and consequences. Journal of the Geological Society 164, 709-730.
CLEMENS, J. (2003) S-type granitic magmas-petrogenetic issues, models and evidence. Earth-Science Reviews 61, 1-18.

Clemens, J., Vielzeuf, D. (1987) Constraints on melting and magma production in the crust. Earth and Planetary Science Letters 86, 287-306.

Clemens, J., WatKInS, J. (2001) The fluid regime of high-temperature metamorphism during granitoid magma genesis. Contributions to Mineralogy and Petrology 140, 600-606.

Clemens, J., Stevens, G. (2012) What controls chemical variation in granitic magmas? Lithos 134, 317-329.

Henk, A., FranZ, L., Teufel, S., OnCKEn, O. (1997) Magmatic underplating, extension, and crustal reequilibration: insights from a cross-section through the Ivrea Zone and Strona-Ceneri Zone, Northern Italy. The Journal of Geology 105, 367-378.

HuANG, F., CHEN, L., WU, Z., WANG, W. (2013) First-principles calculations of equilibrium Mg sotope fractionations between garnet, clinopyroxene, orthopyroxene, and olivine: Implications for Mg isotope thermometry. Earth and Planetary Science Letters 367, 61-70.

LE BRETON, N., THOMPSON, A.B. (1988) Fluid-absent (dehydration) melting of biotite in metapelites in the early stages of crustal anatexis. Contributions to Mineralogy and Petrology 99, 226-237.

LEE, C.-T.A., MORTON, D.M. (2015) High silica granites: Terminal porosity and crystal settling in shallow magma chambers. Earth and Planetary Science Letters 409, 23-31.

Li, W.-Y., Teng, F.-Z., Ke, S., Rudnick, R.L., GaO, S., Wu, F.-Y., Chappell, B.W. (2010) Heterogeneous magnesium isotopic composition of the upper continental crust. Geochimica et Cosmochimica Acta 74, 6867-6884.

LI, W.-Y., TENG, F.-Z., XIAO, Y., HUANG, J. (2011) High-temperature inter-mineral magnesium isotope fractionation in eclogite from the Dabie orogen, China. Earth and Planetary Science Letters 304, 224-230.

LI, W.Y., TENG, F.Z., WING, B.A., XIAO, Y. (2014) Limited magnesium isotope fractionation during metamorphic dehydration in metapelites from the Onawa contact aureole, Maine. Geochemistry Geophysics, Geosystems 15, 408-415.

LinG, M.-X., LI, Y., Ding, X., Teng, F.-Z., FAn, W., XU, Y., Sun, W.-D. (2013) Destruction of the North China Craton induced by ridge subductions. The Journal of Geology 121, 197-213.

LIU, S.-A., TENG, F.-Z., HE, Y., KE, S., LI, S. (2010) Investigation of magnesium isotope fractionation during granite differentiation: implication for $\mathrm{Mg}$ isotopic composition of the continental crust. Earth and Planetary Science Letters 297, 646-654.

LuvizotTO, G., ZACK, T. (2009) Nb and Zr behavior in rutile during high-grade metamorphism and retrogression: an example from the Ivrea-Verbano Zone. Chemical Geology 261, 303-317.

PATIÑo DOUCE, A. (1999) What do experiments tell us about the relative contributions of crust and mantle to the origin of granitic magmas? Geological Society Special Publications 168, 55-75.

PatiÑo DoucE, A., Johnston, A.D. (1991) Phase equilibria and melt productivity in the pelitic system: implications for the origin of peraluminous granitoids and aluminous granulites. Contributions to Mineralogy and Petrology 107, 202-218.

QIU, L., RuDNICK, R.L., MCDonough, W.F., BEA, F. (2011) The behavior of lithium in amphiboliteto granulite-facies rocks of the Ivrea-Verbano Zone, NW Italy. Chemical Geology 289, 76-85.

RedleR, C., Johnson, T., White, R., KunZ, B. (2011) Phase equilibrium constraints on a deep crustal metamorphic field gradient: metapelitic rocks from the Ivrea Zone (NW Italy). Journal of Metamorphic Geology 30, 235-254.

SCHMID, R., WoOD, B. (1976) Phase relationships in granulitic metapelites from the Ivrea-Verbano Zone (Northern Italy). Contributions to Mineralogy and Petrology 54, 255-279.

SCHNETGER, B. (1994) Partial melting during the evolution of the amphibolite-to granulite-facies gneisses of the Ivrea Zone, northern Italy. Chemical Geology 113, 71-101. 
Shen, B., Jacobsen, B., Lee, C.-T.A., Yin, Q.-Z., Morton, D.M. (2009) The Mg isotopic systematics of granitoids in continental arcs and implications for the role of chemical weathering in
crust formation. Proceedings of the National Academy of Sciences 106, 20652-20657.

Stevens, G., Villaros, A., Moyen, J.-F. (2007) Selective peritectic garnet entrainment as the origin of geochemical diversity in S-type granites. Geology 35, 9-12

Telus, M., Dauphas, N., Moynier, F., Tissot, F.L.H., Teng, F.-Z., Nabelek, P.I., Craddock, P.R., GROAT, L.A. (2012) Iron, zinc, magnesium and uranium isotopic fractionation during continental crust differentiation: The tale from migmatites, granitoids, and pegmatites. Geochimica et Cosmochimica Acta 97, 247-265.

Teng, F.-Z., Li, W.-Y., Ke, S., Marty, B., Dauphas, N., Huang, S.-C., Wu, F.-Y., Pourmand, A. (2010a) Magnesium isotopic composition of the Earth and chondrites. Geochimica et Cosmochimica Acta 74, 4150-4166.

Teng, F.-Z., LI, W.-Y., Rudnick, R.L., GARDNeR, L.R. (2010b) Contrasting lithium and magnesium isotope fractionation during continental weathering. Earth and Planetary Science Letters $300,63-71$.

TENG, F.Z., YANG, W., RUDNICK, R.L., HU, Y. (2013) Heterogeneous magnesium isotopic composition of the lower continental crust: A xenolith perspective. Geochemistry, Geophysics, Geosystems 14, 3844-3856.

Tipper, E.T., Galy, A., Gaillardet, J., Bickle, M.J., Elderfield, H., Carder, E.A. (2006) The magnesium isotope budget of the modern ocean: Constraints from riverine magnesium isotope ratios. Earth and Planetary Science Letters 250, 241-253.

Vielzeuf, D., HollowaY, J.R. (1988) Experimental determination of the fluid-absent melting relations in the pelitic system. Contributions to Mineralogy and Petrology 98, 257-276.

WANG, S.-J., TENG, F.-Z., Williams, H.M., LI, S.-G. (2012) Magnesium isotopic variations in cratonic eclogites: Origins and implications. Earth and Planetary Science Letters 359, 219-226.

WANG, S.-J., TENG, F.-Z., LI, S.-G. (2014a) Tracing carbonate-silicate interaction during subduction using magnesium and oxygen isotopes. Nature Communications 5, doi:10.1038/ncomms6328.

WANG, S.-J., TENG, F.-Z., LI, S.-G., HoNG, J.-A. (2014b) Magnesium isotopic systematics of mafic rocks during continental subduction. Geochimica et Cosmochimica Acta 143, 34-48.

Whalen, J.B., CURRIE, K.L., CHAPPeLL, B.W. (1987) A-type granites: geochemical characteristics, discrimination and petrogenesis. Contributions to Mineralogy and Petrology 95, 407-419.

ZINGG, A. (1984) Development Stages of Ivrea Paragneiss (Southern Alps, Northern Italy). Fortschritte Der Mineralogie 62, 266-268. 